\title{
Some studies on enteric parasites of sheep in Beni-Suef Governorate
}

\author{
S. M. Abo El Hadid ${ }^{1^{*}}$, H. S. Lotfy ${ }^{2}$ \\ ${ }^{1}$ Department of Parasitology, Faculty of Veterinary Medicine, Beni-Suef University, Beni-Suef, Egypt \\ ${ }^{2}$ Animal Health Research Institute, Beni-Suef, Egypt.
}

\begin{abstract}
This work was carried out in four selected provinces in Beni-Suef Governorate, Egypt to investigate the possibility of existence of different types of enteric parasites infect 2-5 years old sheep and estimate the rate of improvement in some of its productive parameters post eradication of these parasites in relation to each parasitic infection. The study cleared that gasterointestinal bursated nematodes (Haemonchus spp., Trichostrongylus spp., Ostertagia spp., Nematodirus spp. and Cooperia spp.) and Fasciola are the most common parasites infecting sheep $(57.44 \%$ \& $\mathbf{4 8 . 4 4 \%}$ respectively), this was followed by Paramphistopmum infection (38.88\%), Moniezia spp. (33.11\%), different types of Eimeria spp. (29\%) and finally Trichuris spp (7\%). Fecal culture of positive samples demonstrate presence of five types of nematode larvae include Haemonchus spp. larvae (33.75\%), Oestertagia spp. (31.5\%), Trichostrongylus (11.75\%), Cooperia spp. (14.5\%) and Nematodirus spp. (8.5\%). Using of ivermectin for treatement of GIN, Nitroxynil for treatment of Fasciola, and oxyclozanide for treatment of Paramphistomum species infection, induce marked decrease in the mean number of different eggs per gram (e.p.g.) of faeces associated with improvement in mean body weight gain $(5.71 \mathrm{Kg})$ and rate of lambing (26.77) after 6 months post treatment. High rate of improvement post treatment was recorded in animals originally free from Fasciolia infection, also and that harboring low e.p.g. than animals of high e.p.g. Finally it was evident that high rate of improvement was cleared in animals less than 4 years old in comparison by that over 4 years old.
\end{abstract}

Sheep is one of the important sources of meat and wool in Egypt. Internal parasites of sheep are serious problems of live stock production leading to a serious loss of meat and wool production. Parasites of great economic importance are those of the gasterointestinal tract and liver, where the parasites penetrate the mucosa and submucosa of the intestine causing deep-seated inflammation which indirectly affects the reproductive performance of the animals (Radostitis et al., 1994). Gastrointestinal parasites are very common in sheep due to their grazing and watering habits (Godbole et al., 1988). Parasites are considered one of the most common affections, which cause great economic losses (Ammar, 1997).

Infection of sheep by gastrointestinal parasites still constitutes one of the major economic and health problems affecting sheep

* Corresponding author. Tel.: +20 108525674; fax: +20822327982 .

E-mail address: drshawky2001@yahoo.com (S. M. Abo El Hadid). industries, Loss of blood and plasma protein, alteration in protein metabolism, diarrhea and decrease weight gain are the common abnormalities in infected animals. Others include decreased production, costs for treatment, and prophylaxis as well as animal death (Blood et al., 1983; Coop, 1983; Ismail and Hussein, 1988; Moussa et al., 1998; Veneziano, 2004).

Fascioliasis is responsible for marked direct and indirect losses among ruminants in Egypt, including weak production, increased rate of condemned liver, decreased weight gain and productivity and increased susceptibility to different pathogens especially among chronic diseased animals, (Radostitis et al., 1994). The reproductive performance of Fasciola infected animals is usually impaired causing reduction in growth rate of young animals and prolongation of estrus in mature animals (Kumber and Sharma, 1991). Using of ivomec injection for sheep to provide outstanding internal and external parasite control has been approved (Campbell and Benz, 1984). Using of oxyclozanide and levamizal to sheep, produced about $100 \%$ against Paramphistomum 
(Georgiev and Gruev, 1979 and Denev et al. 1982). Nitroxynil was effective against fascioliosis (Kendall and Parfitt, 1975).

Also the using of anthelmintics reduced egg counts (e.p.g.) (Ahmed et al., 1983 and Talabi, 2002). More over, improvement of weight gain (Rehbein et al., 1999), improved fertility rate of ewes (Garcia-Perez et al., 2002) and increase milk yield and birth weight of lambs (Fthenakis et al., 2005). The weight gain of lambs is highest in ewes given separate anthelmintic treatment for Fasciola and nematodes than that given one drug for both parasites (Maingi et al., 2002).

So the aim of the present study was to identify the internal parasites affect sheep in different locality in Beni-Suef Governorate, their prevalence as well as the rate of improvement of some productive parameters of these animals after 6 months post treatment (for lambing arte) and estimate the relation between type of eradicated parasite and rate of recorded improvement in each case.

\section{Materials and methods}

Study sites. The study period extends from March 2004 to February 2005. During this period, a number of 900 ewes' samples were collected from 4 provinces (Beba, El-Fashen, Somosta and Ehnasia) representing the field condition in Beni-Suef Governorate, Egypt.

Parasitological examination. Identified fecal samples were collected from all available sheep in each of the study area, two times per month. After identification of each animal, separate sheet was filled out and included: owner name, locality, age, sex, approximate body weight, date and condition of last parturition, owner's complain and last medication used. The samples were transferred to Parasitology Department Faculty of Veterinary Medicine, Beni-Suef University for examination.

Preparation and examination of fecal samples. Fasciola and Paramphistomum spp eggs were diagnosed using Fluke finder technique according to (Malone et al., 1984), using 2 gram of mixed feces and examination under the microscope in small amount of water in Petri-dish. Concentration flotation technique according to (Soulsby, 1982) was used for diagnosis of other types of enteric parasites as Eimeria spp oocysts, using concentrated salt solution and examination to top layer of the preparation under the microscope after addition of cover slide.

Egg counting technique. Egg count was determined by McMaster technique according to
Soulsby (1982). In order to estimate the level of infection by small eggs as well as to evaluate the efficacy of the drug post treatment according to the following equation: Efficacy of the drug = $\mathrm{a}-\mathrm{b} / \mathrm{a}$ x100 where $\mathrm{a}=$ No. of eggs before treatment, $b=$ No, of eggs post treatment

Diagnosis of lung worms and other larvae. Examination and diagnosis of lung worms and other nematode species was done after cultivation of the fecal sample via modified Baermann technique according to (Burger and Stoye, 1968)

Animal groups and plan of treatment. In order to estimate the effect of parasitic eradication on the rate of improvement of some productive parameters of treated ewes, group from the infected animals was allocated into sub groups according to types of parasitic infection, and level of infection as the following:

Animals infected by Fasciola eggs only as (G-1) of low e.p.g. and (G-2) high e.p.g. Animal infected by G.I.N. only as (G-3) low e.p.g. and (G-4) high e.p.g. Animals infected by different parasites which could be differentiated into animal infected by Fasciola and G.I.N. (G-5) and animal infected by mixture of parasites (G6). Infected non-treated control ewes (G-7) include sub-groups represent each of the previous conditions (7-1 to 7-6) as in (Table 6). Non-infected non-treated (Healthy control ewe) (G-8). Parasitic infection status and the mean body weight and lambing rate of these animals were re evaluated directly before administration of drug treatment. At the end of 6 months post treatment of these animals, different degrees of improvement was recorded via re-estimation of the previous parameters.

Drug treatment. Three drugs were used for treatment of the infected cases directly after their diagnosis: 1- For treatment of gastro-intestinal nematodal infection. Ivermectine injection at a dose of $1 \mathrm{ml} / 50 \mathrm{Kg}$ Bwt. 2- For treatment of Fasciola infection: Nitroxynil injection will be applied at a dose of $1 \mathrm{ml} / 25 \mathrm{Kg}$. Bwt. subcutaneous injection. 3- For treatment of Paramphistomum infection: Oxyclozanide ( $\mathrm{Za}-$ nil, $4 \mathrm{ml} / 10 \mathrm{~kg}$. body weight) oral suspension. Regular samples at weekly intervals were collected to evaluate the efficacy of the treatment till one month post treatment. Evaluation of general improvement was estimated at the end of 6 months post treatment

\section{Results}

Incidence distribution of different enteric parasites in examined ewes was illustrated in 
Table (1) where it was cleared that, the predominant one of infection by G.I.N. were $57.44 \%$, followed by Fasciola infection (48.44\%), then by Paramphistomum spp. (38.88\%) Moniezia spp (33.11\%) Eimeria spp. $(29.0 \%)$ and the lowest percentage were recorded for Trichurius spp infection (7.0\%). The high prevalence of all parasites except Fasciola spp. was recorded in Beba locality. ElFashn ewes were highly infected by Fasciola. At the same time, Somosta and Ehnasia showed lower in the common rate of infection by parasites than the two other localities.

Concerning, different types of G.I.N. recorded in infected samples, data in Table (2) demonstrate presence of 5 types of nematode larvae in closely related distribution between the different study sites. The most common one is Haemonchus spp larvae (33.75\%), followed by Oestertagia spp (31.5\%), then Trichostrongylus (11.75\%), Cooperia spp. (14.5\%) and the lowest one was Nematodirus spp (8.5\%) in the whole Governorate.

The data in Table (3) demonstrate the parasitic and production rates of the selected groups of ewes before treatment. The changes in the previous mentioned parameters (Table 3) after 6 months post treatment were explained in Table (4). The data in this table demonstrated that there was marked improvement recorded in each group of ewes. Complete freedom from parasitic eggs was noticed in animals that originally had low eggs per gram of feaces than that of high eggs per gram. At the same time, the improvement in weight gain was also higher in such groups especially in animals of young ages than that of old ones.

Animals with previous Fasciola infection showed lower weight gain $(6.1 \mathrm{Kg} \& 5.0 \mathrm{Kg} /$ month) in comparison with that originally infected by G.I.N. only (7.0Kg \& $6.3 \mathrm{Kg} /$ month) in (low and high e.p.g. infected animals respectively). Less improvement response post treatment was recorded in animals of mixed infection. (Weight gain was $4.5 \mathrm{~kg} /$ month).

The profile recorded in weight gain appeared clear also on estimation to the improvement in rate of lambing, The increase in lambing rate post treatment of G.I.N. infection reached to $(30 \%$ and $29 \%)$ in low \& high e.p.g. groups, and to $(26.6 \%$ and $25.0 \%)$ in case of previous Fasciola infected animals after 6 months post treatment.

As in case of weight gain, the lowest rate of improvement in rate of lambing was recorded in animals infected by more than one type of parasite (23.44\%).

These data become more significant in comparing the condition of each animal before and post treatment (Table 4) as well as comparing them with the data of control infected non-treated and healthy control groups demonstrated during the same period (Table 5).

\section{Discussion}

The parasitic infection particularly in Egypt represents an important cause of direct and indirect losses in farm animals. The direct losses include not only the actual mortalities but also severe degree of morbidity resulting in decrease in weight and production. The indirect, damages are not easily evaluated as the infection runs usually in subclinical long standing course including retardation in growth with loss of body weight ( Radostitis et al., 1994).

The infection rate by Fasciola was (48.44\%), is similar to results obtained by Morsy et al. (2005) in Al Fayoum in sheep (40\%) and treated the infected sheep by Mirazid which showed no egg at post treatment examination. Also the present results differ with El Sayed (1997) who reported the rate of infection by Fasciola (6.4\%) in Dakahlia Province. This variation might be related to the application of specific drugs as prophylaxis control programs within regular intervals in some Egyptian province.

Concerning gastrointestinal nematodes, the infection rate $(57.44 \%)$ with in the range of result obtained by Shawkat et al. (1991) who recorded infection rate by PGI in Egypt (65.83\%), El Sayed (1997) at rate of 46.4\%. But these results differ with Ammar (1997) at Kafr El-Sheikh (39.1\%) and Torina et al. (2004) who found rate of $78 \%$ in Sicily, Italy. Ivomec, as drug for treatment of gastrointestinal nematodes was found to be effective and eggs disappeared at $1^{\text {st }}$ week post-treatment and the body gain was increase after one moth. This result agrees with Campbell and Benz, (1984).

For Monizia spp., (33.11\%), it differs with Fakae, (1990) who recorded it at (6\%) in Nigeria and El-Sayed, (1997) at $2.4 \%$. Trichuris spp. infection rate was $(7.0 \%)$ and disagree with Fakae, (1990) who found it at rate of (3.5\%) and Mottelib et al. (1992), who recorded rate of (13 $\%$ ) in Saudi Arabia and with El-Sayed (1997) $4.8 \%$.

Concerning the rate of Paraphistomum species infection $(38.88 \%)$ the result differ with, Fakae (1990) who recorded rate of $(0.9 \%)$ and 
Table (1): Distribution of different enteric parasites in the examined sheep in different provinces of Beni-Suef Governorate .

\begin{tabular}{|c|c|c|c|c|c|c|c|c|c|c|c|c|c|}
\hline \multirow{3}{*}{$\begin{array}{l}\text { Examined } \\
\text { localities }\end{array}$} & \multirow{3}{*}{$\begin{array}{c}\text { No. } \\
\text { examined } \\
\end{array}$} & \multicolumn{12}{|c|}{ Different parasites diagnosed in fecal examination } \\
\hline & & \multicolumn{2}{|c|}{$\begin{array}{c}\text { Fasciola } \\
\text { eggs }\end{array}$} & \multicolumn{2}{|c|}{ G.I.N. eggs } & \multicolumn{2}{|c|}{$\begin{array}{c}\text { Moniezia } \\
\text { eggs }\end{array}$} & \multicolumn{2}{|c|}{$\begin{array}{c}\text { Trichuris } \\
\text { eggs }\end{array}$} & \multicolumn{2}{|c|}{\begin{tabular}{|c|}
$\begin{array}{c}\text { Paramphistomum } \\
\text { eggs }\end{array}$ \\
\end{tabular}} & \multicolumn{2}{|c|}{$\begin{array}{c}\text { Coccidia } \\
\text { oocysts }\end{array}$} \\
\hline & & No. & $\%$ & No. & $\%$ & No. & $\%$ & No. & $\%$ & No. & $\%$ & No. & $\%$ \\
\hline Beba & 250 & 130 & 52 & 166 & 66.4 & 95 & 47.5 & 38 & 15.2 & 105 & 42 & 100 & 40 \\
\hline El-Fashn & 250 & 150 & 60 & 160 & 64 & 80 & 32 & 25 & 10.0 & 95 & 38 & 66 & 26.4 \\
\hline Somosta & 200 & 88 & 44 & 91 & 45.5 & 42 & 21 & - & 0.0 & 80 & 40 & 54 & 27 \\
\hline Ehnasia & 200 & 68 & 34 & 100 & 50 & 81 & 40.5 & - & 0.0 & 70 & 35 & 41 & 20.5 \\
\hline Mean & 900 & 436 & 48.44 & 517 & 57.44 & 298 & 33.11 & 63 & 7.0 & 350 & 38.88 & 261 & 29 \\
\hline
\end{tabular}

Table (2): Different types of nematode larvae detected in the cultivated fecal samples collected from localities.

\begin{tabular}{lccccc}
\hline \multirow{2}{*}{ Season } & \multicolumn{5}{c}{ Mean \% of the deferent larvae in 100 counted larva } \\
\cline { 2 - 6 } & Trichostrongylus spp & Ostertagia spp. & Haemonchus spp. & Cooperia spp. & Nematodirus spp. \\
\hline Beba & 13 & 31 & 29 & 18 & 9 \\
El-Fashn & 11 & 29 & 38 & 14 & 8 \\
Somosta & 13 & 34 & 33 & 11 & 9 \\
Ehnasia & 10 & 32 & 35 & 15 & 8 \\
Mean & 11.75 & 31.5 & 33.75 & 14.5 & 8.5 \\
\hline
\end{tabular}

Table (3): Parasitic infection and production parameters in animals selected for strategic treatment two times / year (April and August).

\begin{tabular}{|c|c|c|c|c|c|c|c|c|}
\hline \multirow{2}{*}{ Type of infection } & \multirow{2}{*}{ Animal group } & \multirow{2}{*}{$\begin{array}{l}\text { No. of } \\
\text { animals/ } \\
\text { group }\end{array}$} & \multirow{2}{*}{$\begin{array}{c}\text { Type of parasite } \\
\text { present }\end{array}$} & \multirow{2}{*}{$\begin{array}{l}\text { No. of } \\
\text { e.p.g. } \\
\text { Min-Max }\end{array}$} & \multirow{2}{*}{$\begin{array}{l}\text { Mean } \\
\text { e.p.g./ } \\
\text { group }\end{array}$} & \multirow{2}{*}{$\begin{array}{c}\text { Mean } \\
\text { bwt (kg) } \\
\text { /Mo. }\end{array}$} & \multicolumn{2}{|c|}{$\begin{array}{c}\text { Lambing } \\
\text { conditions } / 6 \mathrm{Mo}\end{array}$} \\
\hline & & & & & & & rate & $\%$ \\
\hline $\begin{array}{c}\text { Animal infected } \\
\text { by }\end{array}$ & $\begin{array}{c}\text { G-1 ( ewes of 2-3 } \\
\text { years) }\end{array}$ & 15 & Fasciola & $1-3$ & 1.5 & 26.2 & $6 / 15$ & $40.0 \%$ \\
\hline Fasciola Only & $\begin{array}{c}\text { G-2 ( ewes over } 4 \\
\text { years) }\end{array}$ & 20 & Fasciola & $1-6$ & 2.7 & 31.4 & $7 / 20$ & $35.0 \%$ \\
\hline \multirow{3}{*}{$\begin{array}{l}\text { Animal infected } \\
\text { by G.I.N. only }\end{array}$} & G-3 ( Low e.p.g) & 20 & G.I.N. & $\begin{array}{l}1000- \\
3000\end{array}$ & 2250 & 29.5 & $10 / 20$ & $50.0 \%$ \\
\hline & G-4 ( High e.p.g.) & 20 & G.I.N. & $<3000$ & 3650 & 24.6 & $8 / 20$ & $40.0 \%$ \\
\hline & $\begin{array}{l}\text { G-5 (animals of } \\
2-5 \text { years old) }\end{array}$ & 15 & $\begin{array}{c}\text { Fasciola } \\
\text { G.I.N. }\end{array}$ & $\begin{array}{c}1-5 \\
1000- \\
3000\end{array}$ & $\begin{array}{l}1.75 \\
2500\end{array}$ & 37.9 & $5 / 15$ & $33.3 \%$ \\
\hline \multirow{6}{*}{$\begin{array}{l}\text { Animal infected } \\
\text { by different } \\
\text { parasites together }\end{array}$} & \multirow{6}{*}{$\begin{array}{c}\text { G-6 (animals of } \\
\text { 2-5 years old) }(30 \\
\text { animal) }\end{array}$} & 9 & Fasciola & $1-3$ & 1.5 & \multirow{6}{*}{31.8} & \multirow{6}{*}{$11 / 30$} & \multirow{6}{*}{$36.66 \%$} \\
\hline & & 15 & G.I.N. & $\begin{array}{l}1000- \\
4000\end{array}$ & 2200 & & & \\
\hline & & 6 & Moniezia, & $100-500$ & 330 & & & \\
\hline & & 6 & Paramphistomum & $1-5$ & 2.2 & & & \\
\hline & & 7 & Trichurius & $100-300$ & 200 & & & \\
\hline & & 14 & Coccidia & $\begin{array}{l}1000- \\
3000\end{array}$ & 2325 & & & \\
\hline Total & & 120 & & & & 30.25 & & 39.16 \\
\hline
\end{tabular}

e.p.g. $=$ eggs $/$ gram feces 
Table (4): Mean improvement in parasitic infection and production parameters at the end of the year in animals treated in April \& August at the end of the treatment year.

\begin{tabular}{|c|c|c|c|c|c|c|c|c|c|c|c|}
\hline \multirow[t]{2}{*}{ Type of infection } & \multirow{2}{*}{$\begin{array}{l}\text { Animal } \\
\text { group }\end{array}$} & \multirow{2}{*}{$\begin{array}{c}\text { No. of } \\
\text { treated animals } / \\
\text { group }\end{array}$} & \multirow{2}{*}{$\begin{array}{l}\text { Original } \\
\text { parasite } \\
\text { present }\end{array}$} & \multicolumn{2}{|c|}{$\begin{array}{l}\text { Still +ve } \\
\text { Animals }\end{array}$} & \multicolumn{3}{|c|}{ Mean bwt. (kg) / Mo. } & \multicolumn{3}{|c|}{$\begin{array}{c}\text { \% of Lambing conditions / } 6 \\
\text { Mo. }\end{array}$} \\
\hline & & & & No. & $\%$ & $\begin{array}{l}\text { Before } \\
\text { treat. }\end{array}$ & $\begin{array}{l}\text { Post } \\
\text { treat. }\end{array}$ & $\begin{array}{l}\text { Weight } \\
\text { gain. }\end{array}$ & $\begin{array}{l}\text { Before } \\
\text { treat. }\end{array}$ & $\begin{array}{l}\text { Post } \\
\text { treat }\end{array}$ & $\begin{array}{l}\text { Rate of } \\
\text { improve }\end{array}$ \\
\hline \multirow[b]{2}{*}{ Animal infected by Fasciola only } & G-1 & 15 & Fasciola & 0 & 0.0 & 26.2 & 32.3 & 6.1 & $40.0 \%$ & $66.6 \%$ & $26.6 \%$ \\
\hline & G-2 & 20 & Fasciola & 3 & 15.0 & 31.4 & 36.4 & 5.0 & $35.0 \%$ & $60.0 \%$ & $25.0 \%$ \\
\hline \multirow[b]{2}{*}{ Animal infected by G.I.N. only } & G-3 & 20 & G.I.N. & 2 & 10.0 & 29.5 & 36.5 & 7.0 & $50.0 \%$ & $80.0 \%$ & $30.0 \%$ \\
\hline & G-4 & 20 & G.I.N. & 3 & 15.0 & 24.6 & 30.9 & 6.3 & $40.0 \%$ & $69.0 \%$ & $29.0 \%$ \\
\hline \multirow{7}{*}{$\begin{array}{l}\text { Animal infected by different } \\
\text { parasites together }\end{array}$} & G-5 & 15 & $\begin{array}{c}\text { Fasciola } \\
\text { G.I.N. }\end{array}$ & 1 & $\begin{array}{c}6.66 \\
0.0\end{array}$ & 37.9 & 42.4 & 4.5 & $33.3 \%$ & 60.0 & $26.7 \%$ \\
\hline & & 9 & Fasciola & 2 & 22.2 & \multirow{6}{*}{31.8} & \multirow{6}{*}{37.3} & \multirow{6}{*}{4.5} & \multirow{6}{*}{36.66} & \multirow{6}{*}{$60.0 \%$} & \multirow{6}{*}{$23.44 \%$} \\
\hline & & 15 & G.I.N. & 2 & 13.3 & & & & & & \\
\hline & G-6 & 6 & Moniezia, & 4 & 66.6 & & & & & & \\
\hline & (30 ewes) & 6 & Paramphistomum & 2 & 33.3 & & & & & & \\
\hline & & 7 & Trichurius & 0 & 0.0 & & & & & & \\
\hline & & 14 & Coccidia & 0 & 0.0 & & & & & & \\
\hline Total & & 120 & & & & 30.25 & 35.96 & $5.71 \mathrm{~kg}$ & 39.16 & 65.93 & $26.77 \%$ \\
\hline
\end{tabular}


Table (5): Mean change in parasitic infection and production parameters at the end of the year in control negative animal and control infected non treated animals at the end of the observation year (group D).

\begin{tabular}{|c|c|c|c|c|c|c|c|c|c|c|}
\hline \multirow{2}{*}{ Type of infection } & \multirow{2}{*}{$\begin{array}{l}\text { Animal } \\
\text { group }\end{array}$} & \multirow{2}{*}{$\begin{array}{c}\text { No. of } \\
\text { treated } \\
\text { animals / } \\
\text { group }\end{array}$} & \multirow{2}{*}{$\begin{array}{l}\text { Original } \\
\text { parasite } \\
\text { present }\end{array}$} & \multicolumn{2}{|c|}{$\begin{array}{l}\text { Changes in mean } \\
\text { Number of e.p.g. }\end{array}$} & \multicolumn{3}{|c|}{ Mean body weight (kg) / Mo. } & \multicolumn{2}{|c|}{$\begin{array}{c}\text { \% of Lambing conditions / } \\
6 \mathrm{Mo.}\end{array}$} \\
\hline & & & & $\begin{array}{c}\text { At the } \\
\text { Beginning }\end{array}$ & At the end & $\begin{array}{c}\text { At the } \\
\text { Beginning }\end{array}$ & At the end & $\begin{array}{l}\text { Weight } \\
\text { gain. }\end{array}$ & $\begin{array}{c}\text { At the } \\
\text { Beginning }\end{array}$ & At the end \\
\hline \multirow{2}{*}{$\begin{array}{l}\text { Animal infected by } \\
\text { Fasciola Only }\end{array}$} & G-(7-1) & 10 & Fasciola & 2.1 & 2.5 & 27.5 & 30.8 & 3.3 & $50.0 \%$ & $50.0 \%$ \\
\hline & G-(7-2) & 10 & Fasciola & 2.3 & 2.6 & 33.3 & 36.5 & 3.2 & $50.0 \%$ & $40.0 \%$ \\
\hline \multirow{2}{*}{$\begin{array}{l}\text { Animal infected by } \\
\text { G.I.N. only }\end{array}$} & G-(7-3) & 10 & G.I.N. & 2100 & 3200 & 28.5 & 32.5 & 4.0 & $50.0 \%$ & $50.0 \%$ \\
\hline & G-(7-4) & 10 & G.I.N. & 3800 & 4100 & 33.9 & 37.4 & 3.5 & $40.0 \%$ & $40.0 \%$ \\
\hline \multirow{7}{*}{$\begin{array}{c}\text { Animal infected } \\
\text { by different parasites } \\
\text { together }\end{array}$} & G-(7-5) & 10 & $\begin{array}{l}\text { Fasciola } \\
\text { G.I.N. }\end{array}$ & $\begin{array}{c}1.9 \\
2300\end{array}$ & $\begin{array}{c}1.9 \\
2800\end{array}$ & 34.6 & 37.4 & 2.8 & $40.0 \%$ & $40.0 \%$ \\
\hline & & 7 & Fasciola & 2.2 & 2.6 & \multirow{6}{*}{33.3} & \multirow{6}{*}{36.2} & \multirow{6}{*}{2.9} & \multirow{6}{*}{$50.0 \%$} & \multirow{6}{*}{$50.0 \%$} \\
\hline & & 6 & G.I.N. & 2000 & 2800 & & & & & \\
\hline & G-(7-6) & 5 & Moniezia, & 240 & 250 & & & & & \\
\hline & (10 ewes) & 5 & Paramphistomum & 2.0 & 2.2 & & & & & \\
\hline & & 3 & Trichurius & 200 & 400 & & & & & \\
\hline & & 4 & Coccidia & 1750 & 1800 & & & & & \\
\hline \multirow{2}{*}{\multicolumn{2}{|c|}{$\begin{array}{l}\text { Mean } \\
\text { Control non infected animals (G-8) }\end{array}$}} & \multicolumn{2}{|l|}{60} & & & \multirow{2}{*}{$\begin{array}{c}31.9 \\
40.5 \mathrm{Kg}\end{array}$} & 35.1 & 3.3 & $46.7 \%$ & $45.0 \%$ \\
\hline & & (20) ewes & f 2-5 years old & & & & 50.8 & $10.3 \mathrm{~kg}$ & \multicolumn{2}{|c|}{$90.0 \%$} \\
\hline
\end{tabular}

e.p.g. $=$ eggs $/$ gram feces 
El-Sayed (1997) who recorded rate of $11.2 \%$ in Dakahlia Province.

The decline of e.p.g. after treatment that accompanied with an increase in the body gain after treatment was agree with the finding of Ibrahim et al. (1986) in Egypt, in which they noticed that treated animals showed low e.p.g and the mean live weight gain was better than the untreated group of sheep which showed high e.p.g and lower live weight gain. Also the results were similar to that obtained by Hassan and Degheidy, (1986) who mentioned that the untreated sheep infected by Nematodirus spp. showed decline in body weight after one month from infection.

The improvement in rate of lambing in treated group was recorded than in control non treated one, where Stromberg et al. (1997), who said that the reproductive performance and pregnancy rate improved in, treated groups of animals than control untreated one. Also the result go parallel to Yadav, (1997) who found a significant improvement in the birth rate of pregnant ewes after treatment. Samigullin, (1986) noticed that GIN had a negative effect on the digestion and utilization of protein, fat and cellulose which lead to metabolic disorders, increased food consumption and thus causing economic losses either through production or reproduction, but when he treated the infected lambs, the digestion and absorption of nutrients improved 20 days after treatment.

The young animals showed better results than older ones, this may be due to incomplete freedom of these animals from different kinds of parasites in their body or may be due to that they were old in age.

The study cleared that infected animals by parasite other than Fasciola perform good rate of improvement post treatment than that originally has Fasciola infection. This may be due to types of organs destroyed by the parasites (i.e., the degeneration as a result of Fasciola infection in liver considered as irreversible, in comparison to that recorded as a result of G.I.N. infection in intestine).

In conclusion, high rate of improvement as a result of treatment was achieved in animals infected by G.I.N. than that infected by Fasciola. Also, improvement is high in animals of low e.p.g. than that of high e.p.g (one month). At the end of 6 months post first drug administration (for lambing). Therefore care must be taken to the type, level of infection and age of the animal in the production farms in order to estimate the rate of improvement post drug administration, in these farms.

\section{References}

Ahmed, I.; Shafique, M. and Ahmed, A. (1983): Comparative efficacy of oxyclozanide, nitroxynil and hexachlorophene against fascioliasis in sheep. Pak. Vet. J., 3 (1): 37-38.

Ammar, K. M. (1997): Epidemiological studies on nematodes, trematodes and cestodes in ruminants in Kafr El-Sheikh Governorate. $4^{\text {th }}$ Scientific Congress, Egyptian Society for cattle diseases, 7-9 Dec., Assuit, Egypt, (1): 8188 .

Blood, D. C.; Radostitis, O. M. and Henderson, J. A. (1983): Veterinary medicine. $6^{\text {th }}$ ed. Bailliere, Tindall and Cox, London.

Burger, H. and Stoye, M. (1968): Parasitologisohe Diagnostik (Teilil): Eizahlung and larven differenzierung. Therapogen Praxisdienst, 3:1-22.

Campbell, W. C . and Benz, G. W. ( 1984 ) .Ivermectin .a review of efficacy and safety. J. Vet. Pharmacol. Ther,, 7: $1-16$.

Coop, R. L. (1983): The influence of chronic subclinical infection of Trichostrongylus colubriformis on gastrointestinal motility and digesta in sheep. J. Parasitol., 91: 381-396.

Denev, I.; Kostov, R.; Vasilev, I.; Gruev, A. and Tonchev, T. (1982): Study of the therapeutic efficacy of Nilsan preparation against Paramphistomatidae and nematode infections in sheep. Vet. Med. Nauki., 19 (4): 8389.

El-Sayed, H. (1997): Helminth parasites of sheep in Dakahlia Province-Egypt. Assuit Vet. Med. J., 38 (75): 4854.

Fakae, B. B. (1990): The epidemiology of helminthosis in small ruminants under the traditional husbandry system in eastern Nigeria. Vet. Rec. Commun., 14 (5): 381-391.

Fthenakis, G. C.; Papadopoulos, E. and Himonas, C. (2005): Effects of three anthelmintics regimes on milk yield of ewes and growth of the lambs. J. Vet. Med. Physiol. Pathol. Clin. Med., 52 (2): 78-82.

Garcia-Perez, A.L.; Hurtado, A.; Oresui, L. M. and Juste, R. A. (2002): Effects of a second annual strategic anthelmintic treatment in dairy sheep in Northern Spain. Smal. Rum. Res., 43 (2): 121-126.

Georgiev, B. and Gruev, A. (1979): Effectiveness of levamisole and oxyclozanide in paramphistomiasis in sheep and cattle. Vet. Med. Nauki., 16 (3): 45-51.

Godbole, A. D.; Mulay, B. A. and Kulkarni, D. H. (1988): Field trial to study the efficacy of six different anthelmintics on gastrointestinal nematodes in sheep. Ind. Vet. J., (65): 161-163.

Hassan, S.G. and Degheidy, N. S. (1986): Some aspects of productive and reproductive performance in Berki sheep with respect to Nematodirus infection. Egypt. J. Vet. Sci., 23 (2): 175-182.

Ibrahim, M. S.; Omran, H.; Balkemy, F. A.; Mohamed, A. R. and Rae, D. G. (1986): Oxfenbendazole for the control of nematode infestations in Egyptian sheep. Trop. Anim. Health Product., 18 (1): 53-54.

Ismail, M. and Hussein, F. M. (1988) : Studies on the relationship between trace elements and some blood components and fertility in Egyptian buffaloes. Alex. J. Vet. Sci., 4 (1): 555-563.

Kendall, S. B. and Parfitt, J. W. (1975): Chemotherapy of infection with Fasciola hepatica in cattle. Vet. Rec., 97 (1): 9-12. 
Kumber, S. and Sharma, M. G. (1991): Infertility in rural cows in relation to fascioliasis. Ind. J. Anim. Sci., 61 (8): 838-840.

Maingi, N.; Otieno, R. O.; Wed, E. H. and Gichohi, V. M. (2002): Effect of three anthelmintic treatment regimes against Fasciola and nematodes on the performance of ewe and lambs on pasture in the highlands of Kenya. Vet. Res. Commun., 26 (7): 543-552.

Malone, J. B.; Ramsey, R. T. and Loyacan, A. F. (1984): Efficacy of clorsulon for the treatment of mature naturally acquired and 8-weeks-old experimentally induced Fasciola hepatica infection in cattle. Am. J. Vet. Res., 45 (5): 851854.

Morsy, T. A.; Salem, H. S.; Haridy, F. M.; Rifaat, M. M.; Abo-Zenadah, N. Y. and Adel El-Kadi, M. (2005): Farm animals' fascioliasis in Ezbet El-Bakly (Tamyia Center) Al-Fayoum Governorate. J. Egypt. Soc. Parasitol., 35 (3): 825-832.

Mottelib, A. A.; Haroun, M.; Magzoub, M. and ElBasheer, E. (1992): The effect of gasterointestinal parasites on blood picture in sheep and goats at Al-Gassim (Saudi Arabia). Assiut Vet. Med. J., 28 (55): 215-224.

Mousa, W. M.; Ezz-El-Din, N. M. and Abdel-Gawad, H. S. (1998): Haematological, biochemical and histopathological changes in experimentally infected sheep with Haemonchus contortus. Vet. Med. J. Giza, 46 (4): 479-491. Radostitis, O. M.; Blood, D. C. and Gay, C. C. (1994): Veterinary medicine, A text book of the diseases of cattle, sheep, pigs, goats and horses. The English language Book Society and Bailliers Tindall. $8^{\text {th }}$ ed. 1223-1268.

Rehbein, S. ; Corba, J. ; Pitt, S.R.; Varady, M. and
Langholff, W.K. (1999): Evaluation of the anthelmintic efficacy of an ivermectin controlled-release capsule in lambs under field condition in Europe. Small Rum. Res., 33 (2):123-129.

Samigullin, R. N. (1986): Effect of Trichstrongylus on the digesion and utilization of food by sheep. Veterinaryia, Moscow, USSR. 3: 37-39.

Shawkat, E. M.; Abdel-Halim, M. M.; Kubesy, A. A.; Rakha, G. M. and El-Fauomy, M. M. (1991): Clinical and Therapeutic studies on parasitic gastroenteritis in sheep. Vet. Med. J. Giza, 39 (2): 237-254.

Soulsby, E. J. L. (1982): Helmithes, Arthropodes and protozoa of domestic Animals. $7^{\text {th }}$ ed. The English Language Book society and Baillers. Tindall school.

Stromberg, B. E.; Vatthauer, R. J.; Schlotthauer, J. C.; Myers, G. H.; Haggard, D. L.; King, V. L. and Hanke, H. (1997): Production responses following strategic parasite control in a beef cow/calf herd. Vet. Parasitol., 68 (4): 315-322.

Talabi, A. O. (2002): Efficacies of albendazole, levamisole and ivermectin against gasterointestinal nematodes of sheep in Nigeria. Bull. Animal Helth. Prod. Africa, 50 (1): 53-55. Torina, A.; Dara, S.; Marrino, A.M.F.; Sparagano, 0. A.; Vitale, F.; Reale, S. and Caracappa, S. (2004): Study of Gastrointestinal Nematodes in Sicilian Sheep and Goats. Ann. N.Y. Acad. Sci., 1026: 187-194.

Veneziano, V. (2004): Control of gastrointestinal strongyles in goats. , 46 (1-2): 245-50.

Yadav, C. L. (1997): Ovine premature births caused by Haemoncus contortus. Ind. Vet. J., 74: 983-984.

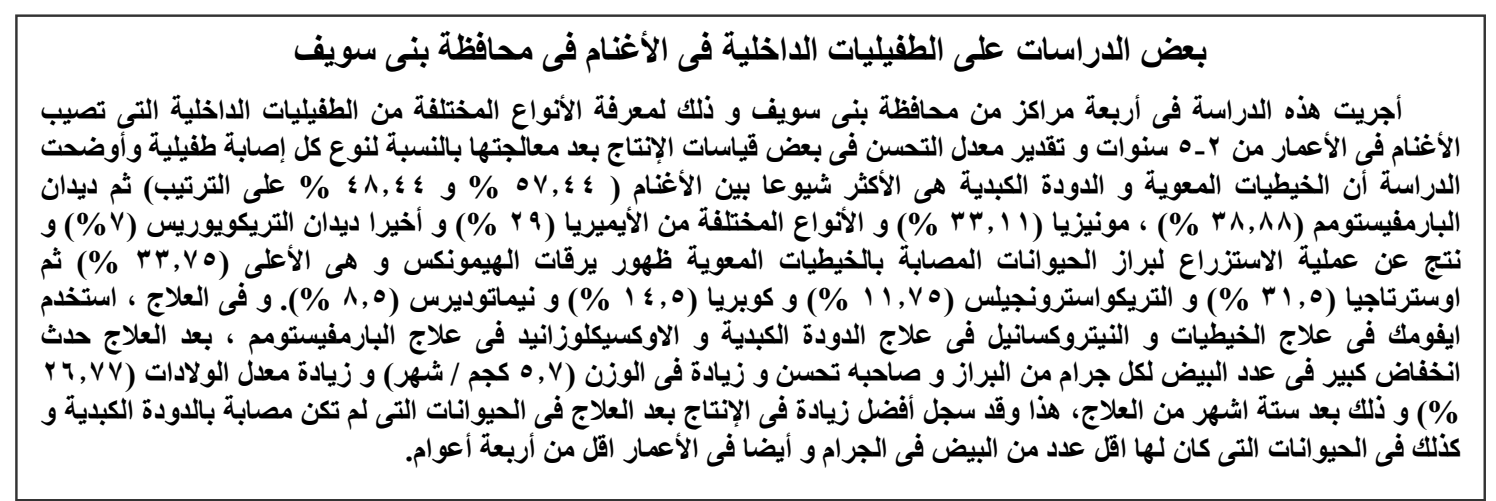

